\title{
Nogle Meddelelser om min Embedsvirksomhed i Staden Slesvig fra 1856 til 1864.
}

Nedskrevne i 1906 af fhv. Herredsfoged A ug. Jørgensen.

Naar jeg efter Opfordring nedskriver fornæunte Meddelelser om en Virksomhed, der begyndte for ca. 50 Aar siden, da skeer det ikke uden Betæenkeligheder af forskjellig Art. Af Arkivalier, der skulde kunne stotte og supplere min Fremstilling, har jeg absolut ingen. Jeg maa ene og alene forlade mig paa min Hukommelse. Men, skjøndt jeg er over 81 Aar gammel, er denne endnu saa levende, at jeg drister mig til at forlade mig paa den, særlig da jo Talen væsentlig kun maa dreie sig om Begivenhederne i storre Træk.

Jeg har bevaret en levende Kjærlighed til den Commune, i hvis Tjeneste jeg traadte som ung Mand. Lige som jeg $\mathrm{i}$ sin Tid tiltraadte den Virksomhed, hvorom der spørges, under Omstændigheder, som jeg vel selv tor kalde for særlig vanskelige, saaledes veed jeg, at jeg kun af Pligtfølelse gav efter for en ikke ringe Pression, naar jeg modtog en Kaldelse, hvis Vanskeligheder jeg havde en med Erbodighed blandet 
Nogle Meddelelser om min Embedsvirksomhed. $\quad 259$

Forudfolelse af. I Aarens Lob har jeg tiet til mange Angreb, der under selve Virksomheden ledsagede denne ikke alene med en vaagen Kritik, men tilsidst med en sand Fanatisme, der gav sig Udtryk i en Flom af Trudselsbreve, Smædeskrifter, ja til allersidst i en i al god Form af den saakaldte slesvigholstenske Executivcommitee udfærdiget og mig tilstillet Dodsdom, der skulde fuldbyrdes en af de sidste Dage af Januar 1864. Ogsaa overfor senere Angreb har jeg forholdt mig taus. Maaskee jeg heri tor soge en Undskyldning for, at jeg, i min høie Alder, gjor et Forsøg paa at fremdrage Kjendsgjerninger, som jeg, der staaer saa at sige foran Dødens Port, mener at skylde Sandlheden, og som jeg tor overtage det fulde historiske Ansvar for.

Som Elev og Student fra Sorø Akademi havde jeg gjennem daværende Lector i Historie C. Fr. Wegeners Undervisning modtaget en energisk Tro paa mit Fædrelands Ret og Pligt til at værge baade sin Nationalitet og sin statsretlige Stilling til Hertugdømmet Slesvig, som denne fremgaaer af de i 1721 afsluttede Begivenheder. I tydsk Sprog (P. Hjort) havde jeg modtaget en saa fortrinlig Undervisning, som neppe siden er given i nogen dansk Skole. Da jeg, efterat have tjent som Menig i de forste Krigsaar, vendte tilbage til det juridiske Studium for at erhverve den Embedsexamen, der ellers skulde være tagen 3 Aar før, maatte jeg selvfølgelig anspænde mine Kræfter til det yderste og var derved bleven ret nøie kjendt af et Par Universitetslærere (A. Fr. Krieger, C. C. Hall), der snart kom til at indtage ledende Stillinger. Fra dem modtog jeg kraftige Opfordringer 
til at indtræde $\mathbf{i}$ Rækken af de Danske, der maatte findes skikkede og villige til at søge den yderligere Uddannelse, der maatte kræves hos lokale Embedsmænd i Hertugdømmet Slesvig. Ulykkeligvis var dette fra national dansk Side hidtil næsten ganske forsømt, ligesom fortroligt Kjendskab til sønderjydsk Eiendommelighed i Sprog, Sæd og Skik, samt i Forvaltningens hele Labyrinth var næsten ganske ukjendt blandt Danskfødte, i skrigende Modsætning til, hvad Tydskfødte, talende og tænkende havde opnaaet ved i Kiøbenhavn at gjore Tjeneste i Regjeringscollegierne, medens de samtidig erhvervede sig grundigt Kjendskab til Forholdene i Monarkiets Hovedlande.

Jeg opfattede da hine Opfordringer fra hoitstillede Mænd som en Opfordring til Frivilligtjeneste paa det antydede Omraade. Udnærnt til Auditeur i Hertugclommerne Holsten og Lauenborg fik jeg fra Mai 1852 fast Station i Rendsborg, hror jeg da, ved Siden af de paa Grund af Forholdene ret alvorlige Auditeurforretninger, af al Magt lagde mig efter Hoitydsk, Plattydsk og et regelret Studium af de Discipliner, der krævedes til en fuldstændig slesvigsk Embedsexamen. Denne absolverede jeg i September 1856 med et saadant Udfald, at min Udnærnelse til Embedsmand fulgte saa at sige umiddelbart efter. Med stor ALngstelse modtog jeg under 22. September Udnævnelse som Politimester og Kongelig Raadmand i Byen Slesvig, eftersom jeg havde en levende Folelse af, hvor stor Afstanden var mellem Theori og Praxis, tilmed i en Stad, hvor de historiske Forhold, ikke mindst paa det juridiske Omraade, havde udviklet sig paa en saa 
Nogle Meddelelser om min Embedsvirksomhed. 261 eiendommelig Maade. Ikke alene var det givet, at jeg i alle Embedsforhold, baade mundtlig og skriftlig, udelukkende havde at betjene mig af det tydske Sprog, men derhos var der en Vanskelighed at overvinde, som ikke kjendes under tilsvarende Forhold for en tiltrædende ung Embedsmand i Kongeriget, hvor et rigt Antal af forud praktiserende baade latinske og danske Jurister altid staaer til Raadighed som Medhjælpere. Jeg var i de Aar, jeg fra September 1856 til Februar 1864 fungerede i Staden Slesvig, udelukkende henvist til at søge den fornødne om end væsentlig kun materielle Bistand hos tydskfødte og tydsktalende Contoirister.

Det første Afsnit af min Embedsvirksombed i Staden Slesvig falder da i Tiden fra 22. September 1856 til 16. April 1860, idet jeg hovedsageligen fungerede som Politimester og Auctionarius, men ved Siden deraf i Egenskab af Kongelig Raadmand deltog i Magistratens administrative og dømmende Virksomhed.

Efter faa Ugers Forløb nødsagedes jeg til at stille den fra Formanden som Politifuldmægtig overtagne Mand Valget mellem kriminel Tiltale eller simpel Afskeed paa staaende Fod. Han valgte det Sidste. Men derved kom jeg i den meget vanskelige Stilling at maatte personlig udføre Alt indtil de yderste Detailler, indtil jeg fik uddannet et brugbart Emne. Denne Omstændighed havde ved Siden af sine Skyggesider den Fordel, at jeg blev fortrolig med Forretningerne $\mathrm{i}$ deres yderste Detail og kunde faae Øie paa Mangt og Meget, som ellers let gaar Principalen forbi. Jeg antog et ganske ungt i Byen barnefødt Menneske og uddannede ham efterhaanden til en routineret Politi- 
fuldmægtig, der, saavidt jeg veed, til den seneste Tid under de nye Magthavere har beholdt denne i mange Retninger betroede Stilling, hrad der formentlig geraader ham til AEre og den hos mig modtagne Uddannelse ialtfald ikke til Forkleinelse.

Jeg foretog meget snart derefter en Reform $i$ det underordnede Personale, idet jeg fjernede, hvad jeg ansaae for mindre heldige Elementer, og erstattede dem med nye. I den Orerbevisning at det er bedre at have færre men forsvarlig lønnede Betjente end talrige slet lønnede, foretog jeg tilsvarende Forandringer og fik paa denne Maade Polititjenesten saavidt paa Høide med rimelige Krav som overhovedet gjørligt. Personlig betragtede jeg mig væsentlig som Communens Embedsmand, der, uden alt andet Hensyn til de øvrige Forhold i Hertugdømmet, havde at varetage denne forlængst udelukkende tydsktalende Byes Interesser og navnlig uden andet Hensyn til Politik, end hvad der maatte paaligge mig som en tro Kongelig dansk Embedsmand, og jeg mener i det Væsentlige at have iagttaget alle de Hensyn, der i saa Henseende kunde være at varetage. At dermed maatte følge en Tilbagevisning af alt, hvad der fra slesvigholstensk Side forsøgte at vove sig frem, er en Selvfølge. Naar jeg troer at turde sige, at jeg loyalt opfyldte Alt, hvad der paa slig Basis med Rimelighed kunde fordres, da slutter jeg dette væsentlig deraf, at jeg i lang Tid kunde opfylde mine Pligter uden at komme i Collision med illoyal Tankegang og illoyal Optræden, der senere, efterhaanden som de politiske Forhold udadtil 
Nogle Meddelelser om min Embedsvirksomhed.

antog skarpere Former, førte til tilsvarende Optræden ogsaa fra min Side.

En Institution, hvis Betydning det er overflodigt at begrunde nærmere, er en større Stads Brandvæsen, ikke mindst i en Stad som Slesvig, der i sin usædvanlige geografiske Udstrækning frembød Farer af særlig Art. Jeg forefandt ved min Enbedstiltrædelse de samme halv- ja heelkomiske Forhold, som vi alle kjende som Barndomsminder fra smaae Byer. Enhver Bydel havde sine Sprøiter med forældet Mekanisme, Slanger af vidt forskjelligt Materiale og Kaliber samt en i høieste Grad mangelfuld Vandforsyning, baseret paa gamle ret skrøbelige Kar, og det gamle System med Vandforsyning ved Kjoring i Sluffer, hvor, navnlig naar Brolægningen er saa slet, som Tilfældet dengang var i Slesvig, en stor Del Vand spildes underveis, medens de uordentlig sammenstrommende Kjoretøier forvolde Trængsel og Ulemper paa Brandstedet. Jeg mindes godt de betænkelige Miner, hrormed min Kritik af det gamle ledsagedes. Men jeg tor maaskee sige, at faa Foranstaltninger have vundet storre Paaskjønnelse i Tidens Længde. De gamle Kar og Sluffer forsvandt, Slanger af nyt Materiale og af ny for hele Byen absolut ensartet Kaliber anskaffedes. Alle Skruegange vare blevne ens, alle Slanger fra de forskjellige Bydele kunde nu skrues sammen til een Længde, om man vilde. Moderne Sugeværker tilvejebragtes; smaae Beholdere med absolut rent Vand kunde, ved Hjælp af de mange Kilder, der fra de omliggende Høider strømmede ned gjennem Byen, anbringes paa passende Steder, saa at rigeligt. og let tilgængeligt Vand sik- 
kredes ethvert Afsnit af Byen i Ildebrandstilfælde. Alt dette vandt efterhaanden Anerkjendelse. Ganske særlig anerkjendtes det nyoprettede Brandkorps, baseret paa faste Grupper af Haandværkere, behørig udrustede til med mindre Mandskab at udfore hver sin Funktion. Det blev i Lobet af kort Tid Byens Stolthed, og jeg har Grund til at troe, at Traditionen i saa Henseende har holdt sig. Det ansaaes for en Ere at tjene i Korpset. De fornøielige Mønstringer bidroge til godt borgerligt Samarbeide, og Resultatet i Ildebrandstilfælde tilfredsstillede Alle. Jeg mindes levende en overordentlig farlig Brand, i Firjahns store Fabrik, som utvivlsomt kun holdtes indenfor Eiendommens Grændser ved det nye Brandkorpses hensigtsmæssige Benyttelse, medens der, om Ilden havde antændt det store Forhus, kunde været overhængende Fare for den tæt sammenbyggede "Altstadt", som Vinden bar paa.

En beslægtet Foranstaltning, der $\mathbf{i}$ forste Øieblik fremkaldte et betydeligt Røre, var Omsorgen for Renligheden i Gaderne. Da Bønner og Opfordringer ikke frugtede, udgik Politiforskrifter med tilføiede Mulktbestemmelser. At disse førte til et Par Politiretssager med Bøder i Hundredvis, vakte Forargelse. Men Resultatet blev, at Borgerne selv paaskjennede denne Omsorg for en Side af det almene Vel, der hidtil var ukjendt. Senere var det saa godt som uhørt, at Indskriden behøvedes. Paa et andet Omraade af mere kilden Natur blev der optaget en systematisk Kamp med en gammel Vane af mindre heldig Art. Det var en indgroet Uskik, at der $\mathrm{i}$ de offentlige Bevært. ninger gaves musikalske Underholdninger af lav Rang, 
hvis egentlige Trækplaster var et kvindeligt Element af utvivlsom tretydig Art. Værterne gjorde de betænkeligste Miner, naar jeg gladeligen gav Tilladelse til musikalsk Underholdning, men med absolut Udelukkelse af ethvert kvindeligt Element af hin Art. Naar man forsikkrede mig, at saa var det Hele spildt, indvendte jeg derimod, at saa var jo ogsaa Beviset fort for, at jeg havde ramt, hvad der burde rammes Og derved blev det. En tilsvarende Bestræbelse for at bekæmpe Drik og anden Usædelighed vandt selvfolgelig ikke Anerkjendelse hos alle.

Af Politiet bør det jo indrømmes, at dets Opgave ikke er at skabe Sædelighed, men kun at bekæmpe Alt, hvad der paa forargelig Maade begunstiger Usædelighed. En Politimester, der optræder med Energi i den her antydede Retning, krydser visse Næringsdrivendes, navnlig Beværternes, Interesser og paadrager sig disses tilsvarende Uvillie, der deles af ligesindede Kunder. Jeg er ikke i Trivl om, at jeg ved min Optræden erhvervede mig Modstandere blandt de paa forskjellig Maade Interesserede, hvad der betyder saa meget mere, naar, som i Slesvig, det vanemæssige Besøg af offentlige Lokaliteter har antaget en constant Characteer og altsaa tilsvarende Droftelser navnlig af Politiets Anliggender indgaae som et fast Led $\mathrm{i}$ visse Samfundslags Underholdning. Jeg berorer dette Moment udførligere, fordi jeg utvivlsomt tor antage, at heri en ikke uvæsentlig Anledning til nogen Misstemning er at søge.

Paa lignende Maade optraadtesskarpt mod tilsvarende Misbrug ved de ikke ubetydelige og ret hyppige Markeder* 
Det turde i Forbindelse med min forudgaaende Fremstilling være Stedet her at skildre en anden Reform af vidtrækkende Betydning. Man behøvede ikke at færdes længe $i$ en By som Slesvig, med én Hovedgade gjennem de 3 Bydele, fra Bustrup gjennem Friederichsberg og Lollfuss til Altstadt, af en uforholdsmæssig Udstrækning, for at opdage, hvilken Plage en forældet Brolægning er, med sine bekjendte toppede Stene og tilsvarende fra planlese Reparationer hidrørende større og mindre Fordybninger, en Plage, der rammer den uformuende Del af Befolkningen ligesaa føleligt som den velhavende. Men ganske særlig spiller det for en saadan Kiøbstads Opland en stor Rolle, om Landmanden med Gru skal tænke paa det Slid paa Heste og Vogne, der følger med et Besog i Kiøbstaden. Jeg forstod snart den oekonomiske Misère, der skjuler sig $\mathbf{i}$ orkeslose og planløse Reparationer af slige Gadestrækninger med illsvarende Udgangsreio paa Byens Grund, samtidig med at de tynge utaalelig paa Byens Budget ved ideligen at gaae igjen uden Udbytte og uden Udsigt til nogensinde at høre op. Jeg sogte Oplysning, bror teknisk Indsigt paa dette Omraade var at finde, og tog mig for at soge Midler til at skaffe Aflijælp paa den mest oekonomiske Maade. Jeg benyttede min Færden paa Jagttoure i Oplandet til at forestille Landmænd, at de i mig vilde finde en villig Kiober af de Sten, som de hellere end gjerne vilde undvære, og som de efterhaanden kunde samle paa beleilige Steder. Jeg fik saaledes lempeligen Leverandører af raae Sten til billig Priis og kunde samtidig give A rbeide med at 
Nogle Meddelelser om min Embedsvirksomhed. 267

sortere og at tilhugge Stenene ligeledes paa lempelige Vilkaar. Jeg opnaaede at have en Cubikfarn equarrerede Sten for ${ }^{3 / 4}$ af den Priis, der samtidig betaltes f. Ex. i Rendsborg. Da Tiden til at opbryde den gamle Brolægning for at give Plads for de nye hugne Sten kom, kunde samtidig en tilsvarende Udsortering blandt de gamle Sten finde Sted, idet en Del med Fordel lod sig omdanne ved at tilhugges, medens de ovrige kunde slaaes til Skærrer og med lige Fordel bruges til Brolægning af Byveiene, som derefter behandledes med paafort Grus o.s. v. Da jeg af Teknikeres Belæring forstod, at en saa at sige daglig Vedligeholdelse af de paa foranforte Maade hovedforbedrede Byveie gjennem øieblikkelig Udjerning af Hjulspor og Smaahuller ved at paafore Smaakvantiteter fra Materialbanketterne giver en enorm Besparelse, medens de nybelagte Vie, naar de overlades til sig selv og til Færdselen, væsentlig forringes i Lobet af kort Tid, fandt jeg paa at bortakkordere denne saa at sige daglige Efterhjælp til de i Nærheden boende Smaafolk. Uden at forsomme deres andet Arbeide kunde de, naar de gik til og fra dette, ved Hjælp af Redskaber, som de lagde fra sig paa Ud- og Hjemtour, paa en for dem næsten umærkelig Maade besorge hine Smaaarbeider paa Veien. Jeg har Grund til at troe, at der paa denne Maade opnaaedes et betydeligt Resultat med ringe Bekostning. Selve Deputeretcollegiets, ॰: Byraadets, Formand (Firjahn) har under Besøg hos mig i Odense Aar senere takket mig for de foran fremstillede systematisk gjennemtænnte og gjennemforte Foranstaltninger, idet 
han tilføiede, at de havde sparet Communen de mange Penge, som den paafolgende Krigstids stærke Færdsel ellers med en grundig Ødelæggelse af Veiene vilde have krævet af Byen.

. Lad mig bemærke, at jeg vel ikke saa lige kan gjore Rede for den kronologiske Rækkefølge, særlig i de senest omhandlede Foranstaltninger, som havde krævet mange Overveielser og forberedende Forhandlinger, men jeg tager ikke feil $i$, at jeg jo allerede som Politimester tog Initiativet til og forberedede de Reformer, hvis Gjennemførelse maatte strække sig ind i det senere Afsnit, da min Virksomhed tillige bler en Borgermesters.

Den Activitet, der var udfoldet i Polititjenesten, bevirkede, at CLefen for det slesvigske Gensdarmeri (Gulstad) besluttede sig til at underlægge mig den stadige Tilgang og Opøvelse af Gensdarmeriets Rekruter, saa jeg $i$ den almindelige Polititjenestes Interesse tillige kunde benytte baade Befalingsmænd og Gensdarmerirekruter og blive istand til at udtale mig for Chefen om de sidstes Anlæg for Tjenesten. I den Anledning leiede Gensdarmeriet den ene Fløi i „Prindsens Palais“, hvis Stueetage og modsvarende Fløi jeg benyttede til Beboelse og Politicontoirer, indtil jeg $i$ 1863 flyttede ind $i$ den gamle Borgermesterbolig $i$ Altstadt. Her havde jeg baade Bolig og Contoirer i det sidste Aarstid før den fjendtlige Occupation.

I Samarbeide med Stadsphycicus (Hauschultz), hvem jeg kjendte fra den Tid, vi begge vare ansatte $i$ Rendsborg, fik jeg bl. a. Fattigsygepleien saa humant organiseret, at det førte til nogen Conflikt med Nabo- 
Nogle Meddelelser om min Embedsvirksomhed. 269

byer, idet jeg opdagede, at man der skilte sig af med sygemeldte Vagabonder ved at udvise dem med Paalæg om at gaae til Slesvig og at anmelde sig der til Sygehusbehandling.

Naturligvis gik der ved Siden af de foran skildrede og særlig frembævede Grene af Polititjenesten en fortlobende daglig Virksomhed for den almindelige Politjtjeneste og for Forundersøgelsen i kriminelle Sager. Hovedadgangen til Hertugdømmet Slesvig Sønder fra forte som bekjendt til Slesvig By, som deraf harde megen Besvær f. Ex. gjennem den aarlig tilstrømmende og senere hjemvendende Skare af arbeidssøgende Jordarbeidere, Teglværksarbeidere o. lign., der stundom modte i stort Antal paa een Gang og altsaa krævede stor Aarvaagenhed i forskjellig Retning paa Grund af Efterlysninger o. desl.

I disse samme Aar, altsaa fra Septbr. 1856 til Foraaret 1860, var min Virksomhed som selvstændig Embedsmand væsentlig den toranskildrede. Men da jeg i dette samme Tidsrum tillige var Kongelig Raadmand, deltog jeg som saadan i Magistratsforretningerne, baade de judicielle og de extrajudicielle, om end selvfolgelig Borgermesteren som ledende og Formand havde det dermed følgende overveiende Arbeide og Ansvar.

Af mange Grunde samstemmede vi hyppigen mindre godt, hvad der foraarsagede ret pinlige Situationer, idet jeg fandt mig ikke alene berettiget, men endog forpligtet til at nægte min Deltagelse i Udfærdigelserne, med mindre jeg kunde faae Adgang til at fremsætte Separatvota. Hrorledes Foresatte have bo- 
domt den saaledes efterhaanden skabte Misstemning, kan og skal jeg ikke yttre mig om.

Men det hele Forhold af den antydede Beskaffenhed fik ganske uventet for mig en Ende derved, at jeg en Dag i April 1860 modtog Underretning om, at den hidtil fungerende Borgermester (Leisner) i samme Egenskab var forsat til Egernforde, medens jeg fra samme Tidspunkt var ulnævnt til Borgermester i Slesvig By i Forbindelse med mit hidtil havte Embede som Politimester og Auctionarius. Forgæves gjorde jeg i den Anledning Forestillinger, stottende mig til, at paa denne Maade Forretninger, der bidtil altid havde paahvilet Trende, nu paabyrdedes mig alene, uagtet jeg eiheller i Egenskab af Borgermester kunde faae anden Medhjælp end den, Contoirister uden al Fagdannelse kunde yde.

Afsnittet fra 16. April 1860 til Februar 1864 fandt mig saaledes stillet i Spidsen for Staden Slesvigs hele, baade administrative og dommende Funktioner i 1ste Instants, og det $\mathrm{i}$ alle de derunder horende mangeartede Grene.

Medens jeg ikke fandt mig berettiget til at nægte at g.jore den Tjeneste, som den ansvarlige Regjerings ledende Mænd lagde paa mine skuldre, men lovede Gud og mig selv at udføre denne Tjeneste saa redeligt, som jeg maatte faa Naade og Kræfter til, stillede jeg strax den bestemte Fordring at blive lønnet med fast Gage istedetfor, som Tilfældet hidtil var i hele Hertugdømmet i slig Stilling, med Sportler. Disse tilsammenlagte for begge Embeder vilde jo have givet mig, der altid som Privatmand har været uformuende, 
en meget betydelig Indtægt. Men jeg gjorde gjældende, at jeg, hvis jeg beholdt denne Indtægt, som Folge deraf i Oppositionens Øjne var udsat for at opfattes som et Kreatur, der skulde begunstiges paa offentlig Bekostning. Ministeren for Slesvig (Wolfhagen), der kom tilstede for at forhandle med mig derom, gjorde gjældende, ikke alene at fast Gagering i slig Stilling ellers var ukjendt, men at Finantsministeren (Fenger) gjorde den Indvending, at naar Embedsmanden ingen personlig Interesse havde af de Sportler, der lovmæssig fulgte med Forretningerne, vilde Fristelsen til at undlade Opkrævningen blive stor. Herimod kunde jeg seierrigt gjore gjældende, at naar det enkelte af Forretningen faldende Gebyr fremtidig tilfaldt Staten, maatte netop det Modsatte blive Tilfældet, idet jeg jo maatte savne enbver Competence til at frafalde Statskassens Ret.

Sporgsmaalet blev derefter, hvilken Storrelse den nye Gage skulde have, og det stilledes mig nogenlunde frit at forlange, hrad jeg maatte onske. Min Henstilling, at man, naar Gagen var bestemt, vilde opslaae Embedet ledigt og see, hvorvidt kvalificerede Ansegere maatte melde sig, blev pure afvist. Jeg bad da om en fast Gage af $6000 \mathrm{Kr}$. aarlig, der strax bevilgedes. Men jeg glemte derved at betænke ikke alene Enbedets Omfang og Ansvar, men at det medforte særlige Repræsentationsudgifter og derhos $\mathrm{i}$ visse Retninger paabyrdede mig usædvanlige Udgifter, idet jeg i dyre Domme maatte betale dansktalende Tyende fra Kongeriget samt holde Blade og Litteratur i begge Sprog, og endelig yde min Tribut til Alt hvad som hæderligt var saavel til tydsk som til dansk Side. Thi vel var 
det mit bestemte Onske, at mine Børn skulde lære baade Plattydsk og Hoitydsk, men ikke mindre, at Dansk skulde vedblive at være Familiens Sprog. Jeg fik snart at føle, at disse Krav stode i Misforhold til Gagen, f. Ex. naar ledende Mænd henviste fremtrædende Personer af fransk (Geffroi), engelsk (Dr. Twiss) eller anden Nationalitet til min Gjæstfrihed. Jeg berører kun disse mere private Forhold for at klargjore, at den mig skabte finantsielle Situation havde sine Skyggesider.

$\mathrm{Da}$ jeg forste Gang satte mig i Formandssædet overfor den samlede Repræsentation af Magistrat og Deputeretcollegiet, erindrer jeg bestemt, at jeg betonede min klare Erkjendetse af det med Stillingen forbundne Ansvar, med det udtrykkelige Tilføiende, at jeg saavidt gjorligt skulde holde al Politik ude af min Færd og tjene Communen, Slesvig By, som var den min egen Fødeby, idet jeg kun tilføiede, at jeg maatte staae som min lovlige Konges tro Tjener, og at derfor Alt, hvad der stred mod fuld Loyalitet mod den Kongelige Myndighed, i mig vilde finde en vaagen og bestemt Modstander. Jeg ilede med at lægge denne min Troesbekjendelse klart for Dagen, idet jeg strax samtykkede i Deputeretcollegiets Forslag om at besætte en ledig Plads indenfor samme med Fabrikant Firjahn. Min Formand havde hver Gang denne Mand tidligere bragtes i Forslag benyttet sin $\mathrm{i}$ Traditionen hjemlede Ret til at forkaste den i Forslag bragte Candidat uden derfor at angive nogen Grund. Jeg fulgte min Overberisning om, at det var klogere at optage en Mand, der absolut besad en overlegen Dygtighed og tilsvarende Interesse for Byens Anliggender, end at forlene ham med den 
Nogle Meddelelser om min Embedsvirksomhed. 273

Nimbus, som en Udelukkelse af Borgernes officielle Raad maatte give ham. Lad mig tilføie, at jeg $\mathbf{i}$ ingen Henseende kom til at fortryde denne min første officielle Liberalitet i min Egenskab af Borgermester. Trertimod, Ingen kunde tvivle om, at jeg i høi Grad paaskjønnede denne Mands for Communen saa værdifulde Dygtighed. Maaskee kan jeg her indskyde, at denne Mand senere har besøgt mig i Odense, hvor vi paa det mest Uforbeholdne have dreftet ikke alene Fortiden, men ogsaa den efter 1864 indtraadte Situation. Han udtalte sin Anerkjendelse af og Interesse for Kongerigske Forhold. Men naar jeg stillede ham det Spørgsmaal, hvorledes han da allerede i 1848 og senere direkte og indirekte havde kunnet sympathisere med den fra tydsk Side brugte Fremgangsmaade mod Alt hrad Dansk var, lød Svaret, ved Siden af en Fordømmelse af de høieste Styrendes Personer saa skarp, at den ikke egner sig til Meddelelse, ordret som følger: „Ich schwärme für ein grosses mächtiges, einheitliches Deutschland “, med Tilføiende, at han ansaae det for Tydsklands Mission at fortydske Danmark til Skagen. Naar Tydskland synes ikke at kunne noies med at have opnaaet den Enhed og Magt, som Tilfældet er, men at tiltroe sig den Mission at opsluge det mest Mulige af alle tilgrændsende Nationaliteter i Syd og Nord, Øst og Vest, da turde det væsentlig være Bestræbelsen for at gjennemføre et saadant Program, der ægger de Nationaliteter til Selvforsvar, hvem en saa nærgaaende Kjærlighed fra tydsk Side naturligen maa forurolige. 
At jeg som Borgermester i den tydsktalende By Slesvig kunde paa det Nidkjæreste samarbeide med en Formand for Deputeretcollegiet som hin Mand overalt, hvor det kun gjaldt communale og finantsielle Interesser, er en Selvfolge. Ingen af os kunde derimod fornægte sin Natur og nationale Opfattelse, naar Begivenhederne udenfra skærpede de rent nationale Modsætningsforhold. Heri og kun heri ligger Forklaringen af det Modsætningsforhold, der i plumpe Hænder maa udarte paa den Maade, som ogsaa blev Tilfældet efterhaanden, som Begivenhederne udviklede dette Modsætningsforhold mellem tydske og Kongelig Danske Synspunkter og Interesser.

Netop ved den Tid, da jeg var bleven stillet i Spidsen for Slesvig Commune, begyndte Situationen udenfor og omkring denne at strammes, og det tor vel ansees for almindelig erkjendt, at det nær var kommet til krigersk Action allerede i Aaret 1861.

I min Embedsvirksomhed, der forsaavidt Polititjenesten angik var bragt $i$ den foran skildrede faste Gænge støttet til et $\mathrm{i}$ det bele ulasteligt underordnet Personale, forte Forholdene med sig, at der maatte skee andre ogsaa personelle Forandringer paa Magistratsomraadet. Leiligheden benyttedes til at ombytte en allerede paa Grund af Alderen mindre velskikket Stadssecretair med en yngre Mand, der fandtes $i$ en sjælden begavet og juridisk udmærket kvalificeret Mand af tydsk Fødsel (Rathjen). Det var en stor Vinding at erhverve en saadan Kraft, ikke alene for de Forretninger, der saa godt som udelukkende vare hans, nemlig Førelsen af Skjøde- og 
Panteprotocoller og den extrajudicielle civile Retspleje, men ogsaa for Forelsen af Forbandlingsprotocollerne for Magistrat og Deputeretcollegium. Vort indbyrdes Forhold saavel paa det tjenstlige som paa Privatlivets Omraade var derfor ikke alene correct, men fuldtud venskabeligt og tillidsfuldt.

En anden Vacance mellem de borgerlige Raadmænd gav mig Leilighed til at faae denne Plads besat med en sand Hædersmand. „Dansk fodt, men Tydsk lært", som han (Peschcke) 'selv kaldte sig, var han gjennem mangeaarig Kaldsvirksomhed bleven fortrolig med Alt og med Alle indenfor Byens Omraade. Hans Egenskab af en varm Menneskeven, der var Enkers, Faderløses og Trængendes fødte Forsvarer, gav ham en i Medborgeres Agtelse urokkelig Stilling, uanseet den ærligste og uforbeholdneste Sympathi for Danmarks naturlige og historiske Ret. Et urokkeligt Venskab knyttede denne Mand til mig og til min Familie lige til hans Død i 1879. Af det Kongelige Hus var han en velkjenilt og skattet Personlighed, hvad jeg fik bekræftet af hans Majestæt Kong Christian IX. ved enhver Audients. paa den skjønneste Maade.

$I$ en større By, særlig $i$ en om jeg saa maa sige historisk By, hvor man idelig og paa de mangfoldigste Maader mindes om svundne Tider, f. Ex. gjennem store offentlige Bygninger (Gottorp Slot, Michaeliskirke, Domkirken, Jobannesk]osteret, talrige milde Stiftelser stammende fra fordums Tiders Slægter og Velgjorere) kommer den Øvrighedsperson, der skal være nær sagt allestedsnærværende i Tanke og Gjerning, ikke mindst $\mathrm{i}$ det daglige Livs løbende Forret- 
ninger, i den Grad i Aande, at der skal Meget til, for at der kan blive Rum for nye og større Planer. Jeg har allerede under det forste Afsnit nærnet forskjellige Foranstaltninger, der maatte fortsættes og, om muligt, bringes til Afslutning under Borgermestervirksomheden, men denne stillede sine ganske særegne store Krav. I forste Række Omsurgen for Byens Indtægt og Udgift med Alt, hvad der i vidtløftigste Forstand falder ind under Begrebet Byens Budget. Allerede som Raadmand havde jeg havt Leilighed til at bemærke, at der svævede ligesom en Taage over Forhandlingerne om Budgettet i Almindelighed og om mange Detailposter i det Enkelte. Dette førte mig ind paa en indgaaende og omfattende Undersogelse af Oprindelsen til og Sammenhængen med hver enkelt Post paa Indtægts- og Udgiftssiden. Dette Foretagende medforte gjennem en vidtgaaende Undersogelse, at hver enkelt Del maatte dokumenteres, droftes og fastslaaes. Resultatet fremtraadte $i$ et ret omfattende Værk, der skulde veilede gjennem Aarsregnskabernes Labyrinth. Jeg lod dette Værk afskrive i 3 Exemplarer, 1 til Afbenyttelse af Borgermestercontoiret, 1 for Deputeretcollegiet og det 3die for Ministeriet. Hensigten var altsaa at skaffe fast Grund under Fodderne ved alle Overveielser og Afgjorelser, i det Enkelte som i det store Hele. Herunder fremtraadte Alt, hvad der vedkom Slien, som et mægtigt Afsnit for sig. Talen var her om Seiladsen fra den saakaldte Havn i Altstadt lige til Sliens Munding, altsaa om Betingelserne for Benyttelsen af denne Vandrei saavel til Seilads som til Fiskeri. Underveis laae ved Slien 
Flækkerne Cappel og Arnæs, der med en forholdsvis betydelig Del større og mindre Fartøier vare stærkt interesserede i Seildybets Beskaffenhed og i Betingelserne for sammes Forsyning med Mærker, Belysning, Bolværker m. m., men forst og sidst dreiede det sig om selve Indseilingen gjennem Sliens Munding, der $\mathbf{i}$ Tidens Løb havde været tilsandet og nu igjen var reguleret. Budgettet vidnede paa den pinligste Maade om en Række rent casuelle Afgjorelser. Hver Gang et storre Arbeide skulde udfores, optoges et større eller mindre Laan med sit særskilte Regnskab, jernlig medførende under et nyt Navn en ny Afgift paa Skibsfarten. Dette Eskesystem var i mange Henseender yderst besværligt, en Plage baade for Yderne og for Byens Regnskabsvæsen samt tilsidst for Ministeriets Control gjennem dettes Revision. For Skipperen var det lidet lysteligt og mindre overskueligt at see, hvad han egentlig havde at betale, endsige hvorfor. Uden Arkivalierne kan jeg her umulig komme ind paa Detailler, men troer ikke at feile, naar jeg siger, at det lykkedes at samle det Adsplittede, tilveiebringe Enhed i Ydelserne og tilsvarende Lettelser i Bogføringen. - En Post under denne Branche erindrer jeg meget levende. Jeg forefandt en gammel næsten constant aarlig Udgiftspost, der kom igjen hveıt dar med omtrentlig de samme Arbeider og Udgifter. De sidste belastede Budgettet med en aarlig Gjennemsnitssum af Tusinder, og det saae ud til at kunne fortsættes i en Uendelighed. Sagen var den, at man for at beskytte og at bevare det nye Indløb til Slien havde paa bver af de 2 Sider opfort saakaldte 
Moler, det vil sige Tømmerconstruktioner af sværeste Dimensioner. Herved dannedes store Kasser fyläte med store Havsteen. Men slige store uregelmæssig dannede Havsteen kunne selvfølgelig kun løseligen sammenpakkes, saa Mellemrummene maae udfyldes med en Mængde ligesaa uregelmæssige Smaasteen; og, hvad der var det Værste, Molernes Overflade blev derved ganske ujærn, hrori Smaasteen som en Art Paksteen spillede den afsluttende Rolle. Hrert eneste Aar kom hele Østersøens Vande i Storm og Isgang mod disse Moler og demolerede dem i større eller mindre Omfang. Kun den, der nøie har iagttaget Bolgeslagets Anfald paa slige Construktioner af den foranskildrede Art, seer og veed, hvad Virkningen uimodstaaelig og uafvendelig er. Hver enkelt Bølge suger og suger, medens den gaaer frem og atter trækker sig tilbage, først de smaae Paksteen, saa, naar en af de store Harsteen er kommen til at ligge blot, denne. Snart har Bølgen løftet den første store Havsteen og kastet den i Vandet udenfor Molen. Ødelæggelsen fortsættes og giver til næste Foraar et tilsvarende Reparationsarbeide med at opfiske de store Havsteen, paany at bringe dem i Leie, at opfylde Mellemrummene med Smaasteen o.s.v. o.s.v. Fiskere fra Cappel-Arnæs og Omeun paatoge sig hvert Aar det omtrent samme absolut nodvendige Reparationsarbeide, der fyldte Tusinder af Kroner i deres Lommer, men dannede tilsvarende Huller i Byen Slesvigs Kasse. Jeg forstod, at det her dreiede sig om Summer, der repræsenterede Renten af en meget stor Kapital, og kom ved mine Overveielser til det Resultat, at den Sag maatte gribes an paa en anden 
Nogle Meddelelser om min Embedsvirksomhed.

Maade, der saavidt muligt sikkrede mod Gjentagelser. Jeg foreslog vor tekniske Consulent, Digeinspectoren (Grove) i Husum, at støbe Molernes Overflader i Betun, sua der dannedes en sammenhængende, jevn for Bølgeslaget uigjennemtrængelig Flade. Derved naaes Formaalet: Bølgen finder ingen Modstand, men glider umærkelig hen over en Overflade, der ikke frembyder en eneste Aabning at slikke ind $\mathbf{i}-$ thi saa er Slaget tabt. Mit Raisonnement var: staaer Betonstabningen kun et Par Aar, er Besparelsen stor nok til at dække Udgiften. Holder Betondækket sig, er en permanent Udgift paa Budgettet skaffet ud af Verden. Arbeidet blev udfort. Dets videre Skæbne er mig ubekjendt.

Tankegangen var en lignende som yed den tidligere omtalte Ombrolægning at gjøre Ende paa en aarlig tilbagevendende, kostbar og unyttig Reparation ved et Arbeide én Gang for alle, selv om dette i første Oiekast maatte være dyrt. Til den Slien vedkommende Beretning hører det at tilføie, at jeg forberedte og paabegyndte et Uddybningsarbeide, der naturligvis kunde ventes at ville oplive den ingenlunde uvigtige Færdsel til og fra Byen Slesvig og saaledes foroge en af Stadens Velstandskilder.

Under mine Granskninger af de aarlige Budgetter fandt jeg en anden uhyggelig, tilbagevendende Post, i Skikkelse af en kostbar Forrentning af Bygjælden. Dennes Hovedsum gik i Hundredtusinder, laante paa saakaldte Byvexler, gjennemgaaende til en Rentefod af $4^{1 / 2}-5 \%$. Byen eiede, i Lighed med andre danske Byer, Jorder af en Udstrækning og $i$ en Kulturstand 
af saa høi Værdi, at Pantesikkerheden var at kalde absolut.

Enhver Forretningsmand vidste, at man i de Tider paa Kieler Omslag med en tilsvarende Pantesikkerhed kunde negotiere store Laan til en Rentefod af fra $3-3^{1 / 2} \%$. Jeg foreslog en Convertering, der vilde give en aarlig Besparelse, som ikke var at foragte. Deputeretcollegiet rystede betænkelig paa Hovedet. Adskillige Velhavende vilde nødig see deres Renteindindtægter reducerede. Man antydede, at en saadan Forholdsregel kunde udsætte Byen for en Katastrofe, om Kapitalerne skulde tilbagebetales. Jeg indvendte derimod bl. a., at jeg, saafremt Forseget mislykkedes, fra et andet Omraade vilde kunne skaffe Midler til Dækning. Laanene opsagdes til Udbetaling, med mindre Kreditorerne samtykkede $\mathbf{i}$ en Reduction af Rentefoden; men denne gik glat paa hele Linien. I „Itzehoer Nachrichten" nedrakkedes nu den Borgermester, der havde trumfet en saadan Convertering igjennem, samtidig med at han for andre af ham forvaltede Institutioner frugtbargjorde Kapitaler dem tilhørende til mindst $4 \%$. At denne saakaldte Inconsekvents, der vel snarere maatte kaldes en consekvent Benyttelse af givne Conjunkturer, indbragte mig en nedsættende Kritik, mente jeg at kunne bære.

Medens saaledes paa adskillige for Stadens Oekonomi ret væsentlige Punkter Gjerningen som Borgermester gik sin jevne Gang, fandtes ogsaa paa andre Omraader Leilighed til snart paa én snart paa en anden Maade at varetage de enkelte Borgeres Interesser. Under Expropriationsforretningerne i Anledning 
af de til Dannevirkestillingen hørende Befæstninger modte den ledende Ingenieurofficer med det Forlangende, at han paa Byens Grund vilde hævde de samme lave Vurderinger, som han havde faaet sat igjennem paa Landet, i tildels magre Egne. Men Haverne bag Friederichsberg vare af Smaafolk ved Behandling med Spaden og stærk Giødning bragte i en saa høi Kultur, at Haveprodukterne gjennem Salget ikke alene indenbyes, men over Jærnbanen til Hamborg-Altona, udbragtes til Priser, der bevirkede, at slige Arealer forrentede store Summer. Som Medlem af Expropriationscommissionen paa Byens Grund hævdede jeg energisk disse Eiendomsbesidderes Interesser derigjennem, at Priser burde lægges til Grund, der stode $\mathbf{i}$ nogenlunde rimeligt Forhold til det Udbytte, den stærke Kultur af Havejorden faktisk indbragte. Min Modstand mod Expropriation til Priser, der under saadanne Omstændigheder kunde $i$ høi Grad forurette navnlig Smaaborgere i denne Bydel, førte til en Conflikt med mig som Borgermester, der antog skarpe Former, idet jeg tilsidst nægtede at deltage $i$ en Forretning, der formentlig traadte Borgernes berettigede Krav for nær. Heraf blev Resultatet, at den ledende Ingenieurofficeer maatte frafalde den af ham hævdede Sætning, at Grundlaget for Priserne skulde være det samme i By som paa Landet.

Under de tidligere rolige Forhold, da Byen husede et Kavalleriregiment paa Gottorp Slot, medens en Bataillon Fodfolk var indkvarteret hos Borgerne, var Forholdet mellem mig paa Byens Vegne og Militairetaten fredeligt. Men med et stillede Krigsministeriet 
det Forlangende til Byen, at den skulde bygge Kaserner, idet man stillede i Udsigt, at Byen maaske ellers ved en Forlægning af Garnisonen kunde udsætte sig for at miste Fordelene for mange Næringsdrivende og Grundeiere ved den hidtilværende Indkvartering. Dette Forlangende fra Militairetatens Side, der senere stilledes og ved Trudselen om at forlægge Garnisonerne overrumplede Myndighederne i endel Kongerigske gamle Garnisonsbyer, modsatte jeg mig som Borgermester i Slesvig By absolut, idet jeg overfor Magistrat og Deputeretcollegium hærdede det Urimelige i, at de communale Skatteydere skulde bebyrdes med de store Udgifter til Kaserneetablissementer, som rationelt maatte ansees for Staten og dens Finantser ene vedkommende, medens en Eftergivenhed fra Communens Side vilde kunne paafore Bykassen store Udgifter og, under Forhold, som Communen ikke havde nogensombelst Indflydelse paa, en meget stor finantsiel Risiko. Da jeg derhos under Forhandlingerne indenfor Bycollegierne med Styrke hævdede, at jeg maatte ansee det for umuligt for Militairautoriteterne at gjennemfore Trudselen om at forlægge Garnisonen, opnaaede jeg Tilslutning til den af mig forfægtede Position. Resultatet blev, som jeg forudsaae, at Garnisonen blev hror den var, og at Byen undgik at inddrages i Forviklinger af vidtrækkende finantsiel Betydning.

Der er Grund for mig til at fremhæve, at, omtrent samtidig med min Udnævnelse til Borgermester fik Byen i den nye Chef for Infanteribrigaden samt Indehaver af Stillingen som Commandant i General Wilster en saa nobel Personlighed, at det blev saare let for 
mig at yde min Medvirkning paa Byens Vegne til at tilveiebringe det onskelige Forhold mellem Civil- og Militairetaten. Ansættelsen af en Garnisonspræst ved Slotskirken paa Gottorp skabte Muligheden af at tilfredsstille den dansktalende Garnison, men, idet det stilledes Enhver i Staden frit at slutte sig til denne Garnisonsmenighed, kom denne faktisk til at staae som en Slags Frimenighed, til hvilken ogsaa jeg med Familie kunde slutte mig uden derved at komme i nogen Conflikt med mit tjenstlige Forhold til tydsktalende Myndigheder ved Byens, forskjellige Sognekirker. Jeg er mig heller ikke bevidst nogensinde at være kommen i noget uvenligt Forhold til disse sidstnævnte Myndigheder, idet jeg meget mere ved enhver Leilighed i Gjerning beviste min Interesse for Kirke og Skole. Denne min Interesse for Skolerne og Ungdommen kunde jeg med Glæde lægge for Dagen ogsaa ved mindre betydende Leiligheder. At en Lærer under min Nærværelse ved en Examen henledede min Opmærksombed paa en Dreng af fattige Forældre, der syntes at røbe kunstneriske Anlæg, førte til, at jeg fik en kiøbenharnsk bekjendt kunstnerisk Autoritet til at komme over for at undersøge Drengens Skolearbeider. Jeg mindes de spændte Miner, hvormed Drengen saae Professoren rask at gjennemblade hans Tegnebog paa en Maade, som ikke syntes at varsle noget Betydeligt. Men da saa Drengen kom frem med et Par Smaaarbeider, han havde modelleret i Gibs paa fri Haand, meddelte min Ven mig, at her robede sig et Talent, der fortjente at fremhjælpes, hvad der, efter som Billedhuggeren Bissen d. Eldre jo selv var fodt 
i Staden Slesvig, skete: Bissen tilbad at modtage det unge Menneske (Hoffmann) i sit Atelier. Jeg tilveiebragte de fornedne Midler til Drengens Underhold i Kiobenhavn, hvor han efterhaanden skred fremad gjennem den sædvanlige Udvikling, dels i Bissens Atelier, dels paa Kunstakademiet, hvor han opnaacde Prisbelønning og Stipendier, saa han kunde optræde som Billedhugger, der har udført Arbeider, der have forskaffet ham baade offentlig og privat Anerkjentelse. Under Opholdet i Rom blev han gjennem en Aarrække den danske Consuls Eftermand. Et andet Tilfælde gav mig Anledning til at redde en senere noksom bekjendt Runesteen, i hvis Text Navnet „Hadeby“ forekommer. Da jeg en Dag spadserede ad den brede Udgang fra Friederichsberg ad Bustrup til, faldt Solen tilfældig paa en paa den modsatte Side af Gaden liggende stor Steen, som Stenhuggeren allerede lavede sig til at kløve. I denne eiendommelige Belysning opdagede jeg Runeindskriften og beordrede paa Stedet Stenhuggeren at afstaae fra at kløve Stenen, idet jeg selvfølgelig garanterede ham en rimelig Erstatning. Paa min Indberetning til det slesvigske Ministerium resolveredes bl. a., at Runestenen skulde bevares og opsættes igjen, hvor den var funden, nemlig i den Gjennemskæring af Dannevirkevolden, som Rendsborgchausseen danner. Dette skete, og Runestenen er reddet for Historien og for dens rette Hjemsted. Herved falder en anden Oplevelse mig ind, der belyser sproglige Forhold fra den nyeste Tid. En Dag fremstillede en Politibetjent for mig en Bonde, der var sigtet for en ubetydelig Overtrædelse af Torveordenen. Jeg afhorte Bonden til en Protocol, 
selvfølgeligen paa Tydsk. Bonden forklarede, at han var en Mand i sin bedste Alder, barnefedt i den ca. $3 / 4$ Mil Nord for Byen Slesvig beliggende Landsby Idsted, hvor han til den Dag altid havde boet. Ganske tilfældig troede jeg i Bondens Tale at høre en eller anden dansk Vending, hrorfor jeg pludselig paa Dansk spurgte ham, om han forstod Dansk? Hertil svarede Bonden ordret: „forstaaer $\circledast$ ikke Dansk', jow $\infty$ forstaacr Dansk, for $\circledast e^{\prime}$ en Dansker, og det vil $æ$ bliw all min Dauw"! Dette paa det reneste Jydsk afgivne Svar foranledigede mig til det Spørgsmaal, om Manden da ogsaa havde forklaret Sandhed, naar han havde an. givet at være barnefødt $i$ Idsted og aldrig at have forladt denne Landsby. Bonden fastholdt paa det reneste jydske Maal, at hvad han havde forklaret om sig selv var Sandhed, men: „mi Dætter" osv., og dermed berettede han, hvorledes Datteren gjennem den tydske Undervisning var paa Vei til at forlade sit Modersmaal.

En eiendommelig Borgerfest, det periodisk tilbagevendende saakaldte "Schützengilde“, har jeg med Glæde bevaret i Erindringen. Der var Fest over den hele By. Ethvert Hus smykkede sig paa det Bedste, og det Skjønneste derved var, at for aabne Døre modtoges enhver Besøgende, uden Hensyn til Stand eller Stilling, og beværtedes paa det Bedste. Hovedsagen, ialtfald saaledes som jeg opfattede den, var den, at paa denne Dag kjendte man kun til Fred og god Forstaaelse, hvoraf Samtalen fik det mest uforbeholdne Præg. Jeg mindes endnu med Glæde sammen med min Hustru at have vandret omkring og tilsidst at 
have præsideret paa Raadhuset og sammen med Borgere og Fiskere at have deltaget i en "Ehrentanz". At Kvindernes Deltagelse i Festen ræsentlig bidrog til at give denne et saa elskværdigt Præg, har jeg i senere Aar ikke alene mindedes med oprigtig Glæde, men, under helt andre Forhold, t. Ex. i Odense, sarnet dette Element, der hører til, for at en Borgerfest kan blive, hrad den bør være.

Medens Forholdene under dette Afsnit af min Embedsvirksomhed i saamange Maader formede sig lykkeligen inden Døre, voxede udenfra den Bevægelse, der havde fostret Krigen 1848-1850, og som fra tydsk Side vedligeholdtes og uddybedes paa enhver Maade og $i$ et Øiemed, som de senere Begivenheder have stillet i fuldt Lys. I Byen Slesvig forfattedes og kolporteredes Skrifter, der betegnedes og kjendetegnede sig selv som sigtende til blodig Vold. Jeg sigter herved til de saakaldte „blodige Adresser". Jeg har intet Exemplar af Arten til min Raadighed, men tor frit paastaae, at, hvis tilsvarende Adresser fra dansk Side nu vovede sig frem $\mathrm{i}$ den nordlige Deel af Sønderjylland, da vilde man i korteste Frist opleve Høiforræderi- og Majestætsfornærmelsessager med et Udfald, som ikke turde være trivlsomt. At Hs. Majestæt Kong Frederik VII. dengang var Landets lovlige Regent, vil dog nok Ingen vove at bestride, og at Machinationer af hin Art ogsaa maatte tildrage sig min Opmærksomhed som kongetro Embedsmand i Slesvig By, var vel selvfølgeligt, om jeg end ligesaa selvfolgelig havde en sikker Følelse af, at der ikke kunde bruges Vaaben af den Art, som den Dag idag utvivlsomt vilde komme 
Nogle Meddelelser om min Embedsvirksomhed.

til Anvendelse $i$ det til den preussiske Krone lagte Land. Jeg havde en bestemt Mistanke om, at hin Adressebevæegelse udgik fra Dr. Heiberg i Slesvig By, og at den ialtfald støttedes af ham. Da jeg derfor fandt en fra Aarene omkring 1830 stammende, fra det daværende slesvigholstenske Cancelli udgaaet, til alle underordnede Myndigheder rettet Anrisning paa at have et vaagent $\varnothing j \mathrm{je}$ med og, om fornodent, at skride præventivt ind imod de saakaldte Frihedsbevægelser, som dengang gik ogsaa gjennem en stor Deel af det tydske Folk, og det af det slesvigholstenske Cancelli særlig var paabudt at skride præventivt ind mod Boghandeler, der kunde antages at støtte slig Bevægelse, fandt jeg efter moden Overveielse at kunne og at burde skride advarende og standsende ind ved at lukke den heibergske Boghandel. Denne Lukning foretoges $i$ og var udelukkende rettet imod den egentlige Boghandels Lokaler, der forsegledes. Jeg har for et Par Aar siden tilfældig faaet et Exemplar af Fru Dr. Heibergs Erindringer ${ }^{1}$ ) i Hænderne og deraf med oprigtig Glæde erfaret gjennem Forfatterindens $\mathrm{i}$ det Stykke vistnok uforkastelige og utvetydigste Tilstaaelse, at min fornævnte Mistanke imod hendes Egtefælle og hans Forretning har været fuldt beføiet. Fruen skildrer i de mest levende Farver den Uro og Angst, hvori Dr. Heiberg efter Boghandelens Forsegling levede, fordi han vidste, at, om en Husundersogelse anstilledes $i$ Bogladen, vilde den lade de

1) Asta Heiberg: Erinnerungen aus meinem Leben, 2te Auflage Berlin 1897 p. 190 sqq. 
haandgribeligste Beviser falde i Øvrighedens Hænder. Fruen beretter, hvorledes Dr. Heiberg var saa at sige lammet af en Skræk, der forst forsvandt, da Hustruen paa en nærmere beskreven Maade om Natten skaffede sig Adgang til den af Ørrigheden forseglede Boghandels Lokaler, og hvorledes hun paa denne Maade blev istand til at bringe de uheldsvangre Dokumenter i Sikkerhed og at gjenreise sin Husbonds Livsmod.

Denne Fru Heibergs aabne Tilstaaelse maa jeg selvfølgelig sætte høi Pris paa, fordi hun dermed rammer alle de lidenskabelige mod mig rettede Angreb, der $\mathrm{i}$ sin Tid betegnede den af mig brugte Politifor anstaltning som en skrigende Uretfærdighed.

Saavidt jeg veed, er Forfatterinden Fru Dr. Heiberg senere afgaaet ved Døden, saa jeg allerede af den Grund ikke kan ønske at tage til Gjenmæle imod hendes mod mig personlig, i et med mit Navn overskrevet særligt Kapitel rettede Angreb. Kun mener jeg at turde henlede Opmærksomheden paa den poetiske Høide, Fru Dr. Heiberg i sine Erindringer kan svinge sig op til, naar hun f. Ex. beretter, hvorledes Kong Christian IX. i Januar 1864 passerede Fruens Vinduer „am Stadtwege“ i Slesvig By, iført civil Dragt, ledsaget af 1 eller 2 Herrer i Civil, formentlig paa Veien for at aflægge et Besøg i Domkirken, men omgiven af Gadedrenge og danske Soldater i Træsk ol Forfatterinden har her glemt, hvilken virkelig Soldat Hs. Majestæt var. Mon hun virkelig troer at kunne indbilde det Publikum, for hvilket hendes Erindringer ere bestemte, at de menige danske Soldater gaae i Krig, medforende Træsko? 
Foruden den foran beskrevne Indskriden mod den Heibergske Boghandel havde jeg som Politimester ladet en ung Borger sætte under Anholdelse for en Delagtighed $\mathrm{i}$ den blodige Adresses Colportering, hris Detailler jeg ikke mere erindrer. Efter et Par Dogn hængte han sig i Arresten. Da en Slægtning bad mig at forskaane Familien for Ligets Aflevering til Anatomikammeret i Kiel og at tillade den at afhente Liget for at lade det begrave, samtykkede jeg deri, og jeg paatog mig Ansvaret for denne Tilsidesættelse af det bestaaende Lorbud. Istedetfor at paaskjønne denne Liberalitet demonstreredes der ved Ligets Afhentning, og det Skete udbasunedes som et Justitsmord. Paa fornyet Anmodning tillod jeg desuagtet en stilfærdig Begravelse, under Ledsagelse af et moderat Antal af Slægt og Venner. Men da jeg erfarede, at man, med Tilsidesættelse af mit Paabud i saa Henseende, havde forberedt en Ligbegængelse med demonstrativ Ledsagelse af udenbyes Deltagere en masse, traf jeg mine Forholdsregler for at forcbygge dette. I Spidsen for mine Undergivne mødte jeg personlig i Galla og standsede Massen, der, i det Øjeblik Ligtoget satte sig i Bevægelse, strømmede ud fra de nærmeste Huse i Lollfuss. Skjondt stærkt ophidsede fandt Lederne det raadeligt at adlyde. Men nu strømmede Mængden, ad den samme Vej den var kommen, op i den ovenfor Husrækken til Michaelis Kirkegaard, hvor Jordfæstelsen skulde foregaae, forende Allé. Da Ligtoget var naaet til udfor den Gyde, der forer op til Kirkegaarden, standsede jeg det og gik alene forud op til Kirkegaardsporten, hvor jeg fandt Kirkegaarden og alle Omgivelser 
sort af Mennesker. Rolig befalede jeg i Kongens og Lovens Navn fra Indgangsporten alle at forlade Kirkegaarden og at overlade mig at lade Begravelsen foregaae paa passende Maade. Til min egen Forbauselse blev jeg adlydt, idet kun en Eneste, en ung Mand, stillede sig op ved Graven med korslagte Arme og, paa min Forespørgsel, erklærede at være en tydsk Student, der vel havde hørt mit Paabud, men nu nægtede at adlyde dette. Han blev altsaa anholdt, fort bort, og, efterat have udstaaet en summarisk idømt Straf, udvist. $\mathrm{Nu}$ indtraadte den forberedede Demonstration i sidste og maaske farligste Stadium. Man samlede sig under Ophidselse i Ølkneiperne. Men nu ryddede jeg, personlig anforende, disse, forbod al Sammenstimlen i Gaderne og opnaaede, at den tilsigtede Demonstration opleste sig i Intet. Den beherskede, men bestemte Ro, hrormed der fra Politiets Side blev traadt op, afværgede andre ulykkelige Følger af Ophidselsen, men kunde ikke forhindre en ophidsende A vispolemik, der yderligere æggede Stemningen i Tydskland og gav sig Afleb i Smædeskrifter og Trudsler mod mig personlig. Selvfølgelig indlod jeg mig ikke paa nogen Tagen til Gjenmæle. Maaskee skulde jeg til Dokumentation i kommende Tider have samlet slige Aktstykker, hvad der vilde have dannet et anseeligt Værk. Men kun Dødsdommen med dens Executionsclausul, afsagt af den saakaldte Excecutivkomitee, mener jeg at have tilstillet Bladet „Fædrelandets“ Redaction, efterat den forst $\mathbf{i}$ nogen Tid havde været opslaaet uden paa Døren til mit Embedscontoir til almindelig Efterretning. 
Under de gjentagne Troppesamlinger, der overværedes af Hs. Majestæt Kong Frederik VII., der opslog $\sin$ Leir lige udenfor Bygrændsı $n$ paa Gaarden Falkenbergs Harker, fandt jeg Anledning til at forestille ham, at den ildesindede Presse af den Omstændighed, at Kongen saaledes undgik at passere Byen, tog Anledning til at antyde, at dette var begrundet i Frygt. Kongen tog forsaavidt Hensyn til disse mine Forestillinger, at han anmeldte sit Indtog gjennem Byen til en bestemt Tid og selvfolgeligen blev modtagen paa passende Maade. Jeg har Grund til at antage, at disse og lignende Forestillinger fra min Side have medvirket til, at jeg en seen Eftermiddag i 1863 telegrafisk blev kaldet til Kongen paa Glücksborg Slot, hvor Frederik VII. personlig meddelte mig sin Beslutning i den nærmeste Fremtid at ville komme til Slesvig og at ville tage Bolig hos mig, der jo dengang boede i Altstadt. Selvfølgelig besvarede jeg denne Ordre med Løvte om, at min Hustru og jeg vilde gjore Alt, hrad et borgerligt $\mathrm{HJ}_{\mathrm{j}} \mathrm{m}$ formaaede at yde af Gjæstfrihed. Ved min Hjemkomst traf jeg i den Anledning forskjellige Forberedelser. Jen kort efter foretog saa Kongen den Seilads ned ad Slien, hvorunder et Uveir lagde Spiren til den Sygdom, der forte til hans Død medio November. De paafølgende alvorlige Begivenheder have naturligen udslettet Erindringen om det tilsigtede Kongelige Besøg i Slesvig Byes Altstadt, til hvis gamle Borgermesterbolig jeg var flyttet efter de foregaaende Aar at have boet $i$ "Prindsens Palais" $i$ Friedrichsberg. Jeg har derfor ikke villet undlade at berette om denne Episode, hris eneste praktiske Følge 
blev visse Forberedelser i min Bolig med dertil svarende Udyifter.

Naar jeg har skullet berette om mine Oplevelser som Embedsmand i Staden Slesvig, kan jeg ikke undgaae som et særligt Afsnit at medtage min Virksomhed som Direktor for det Kongelige Dørstummeinstitut for Hertugdømnerne Holsteen, Lauenburg ug Slesvig.

Min Beskikkelse i denne Post modtng jeg samtidig med min Udnævnelse til Borgermester i Foraaret 1860. Da jeg var ganske ubekjendt med Alt, hvad der angik Undervisning og Behandling af Døvstumme, sant da Talen tillige var om at bestyre samtlige de Institutioner og Fonds, der vare knyttede til Døvstummeinstitutet, bad jeg mig indstændigen fritagen for dette betydelige yderligere Tillæg til de mig paalagte andre og omfattende Forretninger. Men da den i saa Henseende tagne Bestemmelse ikke kunde bevirkes tilbagekaldt, maatte jeg finde mig forpligtet til af yderste Evne at gjore mig bekjendt med de herhenhorende Anliggender. Jeg tyede til Raadforsel med Direktøren for det kongerigske Døvstummeinstitut i Kiøbenhavn og gjorde mig efter bedste Erne bekjendt med den, navnlig fra udenlandske Døvstummeinstituter, hidrørende Litteratur. - Forstanderen for det Kiøbenharnske Dørstummeinstitut (Heiberg) ydede mig baade strax og senere i Aarenes L $ø b$ den beredvilligste Bistand, bl. a. ved under Besøg paa Stedet at gjore mig bekjendt med alle herhen hørende Forhold. Derimod at gjøre mig bekjendt med Døvstummeinstitutets hele orrige Organisation og forskjelligartedo Virksombed var en Sag af mere almindelig administrativ Art, der ikke stillede særlige For- 
dringer til mine Qvalifikationer. En Ting, der strax maatte tildrage sig min Opmærksomhed, var, at jeg forefandt en saa naturstridig Ordning som den, at de dørstumme Børn fra danske Hjem i Sønderjylland undervistes i Forening med de andre Døvstumme fra de 3 Hertugdømmers tydske Sprogomraade. Følgen heraf var altsaa, at dørstumme Børn fra dansktalende Hjem i sin Tid ved deres Afgang vendte tilbage til deres Hjem som Fremmede, med deres tydske Bibel, Psalmebog og tydske Skriftsprog. Men hverken Institutets hidtilværende Forstander eller nogen af dets Lærere vilde eller kunde undervise paa Dansk. Jeg fandt at burde afæske samtlige Forældre eller Værger for de døvstumme Børn fra Sønderjyllands dansktalende Egne en Erklæring, om de ønskede deres Børn vedblivende underviste paa Tysk, med Tilføiende, at forsaavidt de maatte onske hver sit Barn undervist gjennem det danske Sprog, vilde der fra Døvstummeinstitutets Side snarest blive truffet Foranstaltning til, at dette Øaske kunde opfyldes. Saasnart det havde vist sig, at et større Antal Børn af rette Vedkommende øuskedes underviste paa Dansk, erhvervede jeg Ministeriets Bemyndigelse til at træffe alle dertil sigtende Foranstaltninger, deriblandt særlig ved at finde og at ansætte en kvalificeret dansktalende Døvstummelærer. Jeg udstedte en Bekjendtgjørelse herom, med Opfordring til Ansøgere om at møde hos mig til opgiven Tid og Sted, medbringende alle onskelige Bevisligheder. Blandt Ansegerne maatte En, Malling Hansen, strax tildrage sig min særlige Opmærksomhed, ikke alene fordi han - allerede i længere Tid havde fungeret som Lærer ved 
det Kiøbenhavnske Døvstummeinstitut og havde bestaaet baade Afgangsexamen fra et Seminarium og derefter Examen artium og philosophicum med Udmærkelse, men fremfor Alt ved sin hele vindende Personlighed. Han antoges med Tilkjendegivende, at han kunde paaregne al fornøden Stotte, saafremt det viste sig, at Forudsætningen om at han var den rette Mand slog til. Dette blev i onskeligste Grad Tilfældet. Uagtet han efter alt Foreliggende modtoges af hele Lærerpersonalet med en til Uvillie grændsende Kulde, erobrede han sig meget snart den onskelige Anerkjendelse for Dygtighed og Omgængelighed, saa det gik som ad slagen Bane, at denne dygtige Mand afløste den hidtilværende renitente Forstander, og at han, uden at træde noget sprogligt Hensyn for nær, bragte alt i den onskeligste Gænge. Det blev en af mine kjæreste Adspredelser at vandre ud til det i min Nærhed beliggende Institut og at forvisse mig om, at de dorstumme Born i Retning af Elskværdighed, Pligtopfyldelse og det Maal af Kundskab, der blev naaet, kunde maale sig med Folkeskolens bedste Børn, hvorfor jeg paa alle Maader stræbte at lempe Alt paa det Bedste baade for Lærere og for Elever. Heldigvis benyttede jeg det Tryk, jeg kunde lægge paa den nye Forstander, til at drive paa, at han skulde tage den theologiske Attestats, hvortil han tidligere havde gjort mindre Tillob. At han fik denne Examen bevirkede, at jeg, efterat vi Alle vare forjagede i 1864, kunde introducere ham hos den vedkommende Minister som den mest kralificerede Candidat til den netop ledigblevne Post som 
Forstander ved det Kiøbenhavnske Døvstummeinstitut, en Ansættelse han da ogsaa opnaaede.

Det var under Forhandlingerne med denne Mand, at jeg for mit Vedkommende kom til det foreløbige Resultat $\mathrm{i}$ den standende Strid mellem Tale- og Tegnmethoden, at den forste kun egner sig for de saakaldte "uegentlig Dørstumme“, allerede af den Grund, at Undervisning i Talesprog overfor egentlig døvstumme Born kræver en saa ganske uforholdsmæssig Deel af den Tid, Barnet kan stille til Raadighed, at Resultatet staaer $i$ et skrigende Misforhold til, hvad der opnaaes. Af den Grund turde jeg for min Deel ikke paatage mig Ansvaret for at lade Talemethoden fuldstændig afløse Tegnmethoden.

Som fungerende Dørstummedirektor maatte jeg dernæst sætte al Kraft ind paa en Omdannelse af Institutets ældre Bygninger og delvise Aflosning med nye. Arbejderne dermed vare i fuld Gang, da Foraaret 1864 gjorde en Ende paa mine Funktioner i hin Egenskab.

I det sidste Aarstid kom en født dovstum og tillige blind Dreng til os fra en Commune. i Holsteen. Selve dette af en sørgelig Skjæbne saa mangelfuldt udstyrede Barn maatte strax vække den høieste Interesse ved sin Livlighed og Evne til at finde sig tilrette. I en Haandevending var han fortrolig med hver Krog paa Institutet, løb over Gangbrædtet, der forte over Bækken bag Institutet, og balancerede, tilsyneladende sikkert, opad Haandværkernes Stiger og, til min Skræk, ud paa det under Ombygningen blottede Bjelkeværk. Efterat han strax havde befølt mig fra 
øverst til nederst og forstaaet, at jeg var øverste Foresatte, vidste han senere strax at finde mig, naar jeg nærmede mig, og kunde $i$ lang Afstand signalisere min Ankomst ved med Gebærder i Luften at vise, at han klappede de Jagthunde, der pleiede at ledsage mig.

Hele Lærerpersonalet erklærede sig ude af Stand til at paatage sig at undervise dette Barn paa rationel Maade. Ved at correspondere med udenlandske Dovstummeinstituter erfarede jeg, at man i Schweiz havde et saadant paa en Gang blindfodt og dovstumt Barn under Behandling med Udsigt til tilfredsstillende Resultat. Paa min Indstilling approberede Ministeriet, at jeg maatte sende Drengen til Schweiz. Men Begivenhederne i Foraaret 1864 standsede for nig ogsaa denne Sag, om hris videre Skjæbne jeg Intet veed.

Dette mærkelige Tilfælde forte nig ind paa en indgaaende Undersøgelse af Kjendsgjerninger, der muligen kunde kaste noget Lys over Anledningen til Dørsiumheden. Jeg gjennemgik samtlige dovstumme Børns hjemlige og øvrige personlige Furhold, der vare optagne i Institutet $\mathbf{j}$, jeg troer, ca. 30 Aar tilbage. Desværre ere de indvundne skematisk fremstillede Rosultater ikke længere i min Besiddelse, idet jeg overlod Materialet til Geheimeetatsraad Trap i Forening med det hele omfangrige Materiale til Staden Slesvigs Historie. Jeg veed Intet om, hvor dette Materiale muligen befinder sig. Men jeg mindes visse Resultater, der forekom mig overraskende, f. Ex. at Hertugdømmerno Holsteen og Lauenburg leverede en jevn Tilgang omtrent dobbelt saa stor som Tilgangen fra Hertugdømmet Slesvig, uagtet Forskjellen i Folketal jo var ubety- 
delig. Jeg bemærkede, at der fra Marsken saagodtsom ikke indkom dørstumme Born, endvidere at der var Distrikter i Hertugdømmet Holsteen, der afgare Flertallet, ligesom visse Familier syntes at være særlig hjemsegte, som f. Ex. den Familie, hrortil hin blindfodte og dorstumme Dreng horte.

Har jeg ond fra min Syssel med Hertugdommernes Dorstummeinstitut beraret en levende Interesse for de saakaldte abnorme Born, saa have Omstændighederne senere stillet saa store Krav til min Arbeidskraft, at jeg ikke har kunnet naae videre end til at behandle de Tilfælde, hvor Døvstumme krydsede min Virksomhed som Herredsfoged paa Fyen, med en særlig Opmærksombed, hvis Resultat kun har bekræftet, hvad jeg fra min Virksomhed som Dorstummedirektør for Hertugdømmerne foran har antydet.

I det Foregaaende har jeg leilighedsris berort, at jeg under den hele journalistiske og litteraire Feide (Moritz Busch m. Fl.) i de seneste Aar af min Virksombed j Slesvig By var bleven beæret med en saa udpræget personlig Forfolgelse, at jeg havde al Anledning til at overveie, hvorledes jeg vilde stille mig til samme. Strax i de forste Uger virkede denue Forfolgelse, der havde samme Characteer, som naar paa visse Parforcejagter Vildtet forfølges af den samlede Meute, stærkt paa mig. Jeg forsegte et Par Ganie at give offentlige Berigtigelser og Erklæringer, men fulgte senere det mig af Præsidenten i Appellationsretten givne Raad at opgive alt Forsvar, da dette kun vilde fore ud i haablose Situationer ligeoverfor Angribere, for hvem Angrebene vare en fagmæssig Bedrift. Lige- 
som jeg i Begyndelsen næsten forfærdedes ved det Pludselige og Lidenskabelige i Agitationen, saaledes blev det mig efter en kortvarig Krise klart, at jeg maatte lade min Samvittighed alene afgjøre det sporgsmaal, om ogsaa den fældede mig. Det ad den Vei modtagne Svar var at den Art, at jeg fremtidig kunde stille mig i Breschen uden at ændse Trudsler om Død og Dom over mig og mine Nærmeste. Jeg' veed kun een Gang at have ladet mig furlede til et Skridt, som med Grund kunde angribes, og som jeg senere altid har beklaget. Det var, da jeg paa en Tid, da den lokale Agitation dreves lidenskabeligt, paa Opfordring leverede en Fortegnelse over en Del af Byens Næringsdrivende efter Delingslinien loyale eller illoyale. Sligt smager af Proscription, og jeg betænker mig ikke paa aabent at erkjende, at jeg dermed har begaaet et Misgreb.

Ellers skal jeg i al Beskedenhed freidig afvente Historiens Dom, om den nogensinde gad uleilige sig med at undersøge min Embedsførelse. Jeg har, efter forlængst at være kommen udenfor Skudvidde, modtaget mange Beviser paa personlig Hengivenhed fra Indvaanere $\mathrm{i}$ den $\mathrm{By}$, jeg for en Aarrække har viet min Manddoms bedste Tid og Kræfter. Kun een Gang har jeg besogt selre Staden Slesvig siden hin Tid. Det var, da jeg i Foraaret 1879 reiste over for at være med at folge Senator Peschcke til Jorden. Hans Jordefærd blev, endskjøndt Himmelens Sluser aabnede sig over os, et $i$ Sandhed imponerende Vidnesbyrd om, at ogsaa en udpræget dansk Mand uimodstaaelig kunde vinde og bevare Medborgeres Agtelse. Den preussiske Geistlige, der talte over den Afdøde, 
Nogle Meddelelser om min Embedsvirksomhed.

aflagde et smukt Vidnesbyrd om upartisk Anerkjendelse af hans usvigelige Troskab mod sin gamle Konge og sit gamle Fædreland.

Mig personlig vederfaredes ved denne Grav, inden den fuldt dækkedes, en liden Hændelse, som jeg maaskee dog har Lov at opfore paa min Credits Conto. Den mest betydende Mand i Borgerskabet kom hen til mig, idet han paa Plattydsk spurgte mig: "Weten Se, wat Le segt, de da steit?", og dermed pegede han paa en gammel, før min Tid afgaaet, noksom tydsksindet Senator. $\mathrm{Og}$ da jeg naturligvis maatte svare, at det kunde jeg jo ikke vide, fortalte han mig, at den gamle Senator til ham havde sagt: "Hest Du de Ohle sehen? Hätten wi de nu mal wedder und könnten all de Preussen in de Slie smiten!“

Jeg maatte paa Opfordring blive et Par Dogn i Byen og erfarede, mens jeg spadserede om, mange Beviser paa personlig Tillid og Hengivenhed, ledsagede af tilsvarende Beklagelser over, hvad der siden hin Tid var skect.

For mit Vedkommende vil jeg dertil kun sige, at vel nærer jeg ingen Tvivl om Oprigtigheden af slige Udtalelser. Men jeg vilde ansee den for en Daare, der ikke kunde see og fornemme, at er det end Magten, der her har skabt Retten, saa. er Magten saa overvældende stor, at det kun er, hvad man kalder „Knips i Lommen" at troe paa, at den tydske Enhedstanke nogensinde frivillig skulde give Afkald paa sit Bytte.

Til Slutning kun et Par Ord om Katastrofens Forlob for mit private Vedkommende.

Vel havde jeg forlængst maattet gjøre mig for- 
trolig med Tanken om, at den danske Armee i Længden umulig kunde andet end at bukke under for Overmagten, hvis det ovrige Europa tillod denne Overmagt at bemægtige sig sit udseete Bytte. Men jeg var ligesaa fortrolig med den Tanke, at jeg personlig maatte bære, hvad der kunde blive min Lod i det almindelige Skibbrud. Heri lod jeg mig eiheller rokke, da en mig dengang og endnu i dette Oieblik ganske ubekjendt Mand kort for Dannevirkes Romning indfandt sig hos mig, idet han gav tilkjende, at han var fra Ditmarsken og kun i Afstand havde fulgt Begivenhederne, deriblandt særlig den mod mig personlig reiste Agitation. Han havde noie seet til og var kommen til det Resultat, at jeg vilde komme til at lide et ligesaa ufortjent som forfærdeligt Martyrium. Han opfordrede mig til itide at sorge for min personlige Sikkeslued, mens endnu Tid var, og stillede sine Penge og Befordring til min Raadighed. Selvfolgelig kunde jeg ikke modtage dette velmente Tilbud og ligesaa selvfolgelig maatte jeg overfor Conseilspræsident Monrad, da han d. 3. Februar 1864 rettede en lignende Opfordring til mig, bestemt afslaae denne. Jeg matte betragte det som horende til mit Embede at varetage dette til det Sidste, komme hrad komme vilde. - Da Monrad imillertid tilkjendegav mig, at det ikke blot var Regjeringens Ønske, men dens Villie, at jeg ufortovet tiltraadte den Orlov, han allerede havde aftalt med min Amtmand, maatte jeg adiyde. Jeg kan derom henvise til mit Svar for godt 1 Aar siden gjennem Dagbladet "Vort Land“ til en paa mindre loyal Maade, 
Nogle Meddelelser om min Embedsvirksomhed. 301 uden at meddele mig det, af Hiort Lorenzen stillet Provokation.

At det, efterat Magtbaverne, de allierede Tropper, havde besat Byen, og efterat man havde delt mit Embede mellem Trende, der uden videre rykkede ind $i$ det Hus, hvor jeg havde baade min Bolig og mine Embedscontoirer, gik haardt ud orer min private Formue, skal jeg ikke trætte med, men kun illustrationis causa anfore, at en af mine hidtilværende Contoirister, med hrem jeg corresponderede derom, skrev: „Es ist zwar nur eine kurze Spanne Zeit rerstrichen, es baben sich aber während der Zeit die Begriffe von Mein und Dein merkbar geändert."

Saavidt muljgt og nodvendigt Lar jeg i disse Meddelelser afholdt mig fra at nævne Navne. Min Sanıvittighed siger mig, at jeg i fuldeste gode Tro kun har meddelt Kjendsgjerningerne. Dommen overlader jeg til Andre. 